Article

\title{
An Inter- and Transdisciplinary Approach to Developing and Testing a New Sustainable Mobility System
}

\author{
Laura Gebhardt ${ }^{1, *}$, Mascha Brost ${ }^{2}$ and Alexandra König ${ }^{3}$ (D) \\ 1 Institute of Transport Research, German Aerospace Center, 12489 Berlin, Germany \\ 2 Institute of Vehicle Concepts, German Aerospace Center, 70569 Stuttgart, Germany; mascha.brost@dlr.de \\ 3 Institute of Transportation Systems, German Aerospace Center, 38108 Braunschweig, \\ Germany; alexandra.koenig@dlr.de \\ * Correspondence: laura.gebhardt@dlr.de
}

Received: 31 July 2019; Accepted: 7 December 2019; Published: 16 December 2019

check for updates

\begin{abstract}
Sustainability research is frequently tasked with the development of concrete solutions that can be directly applied to socio-environmental problems as such this paper presents and discusses an inter- and transdisciplinary approach to developing and testing a mobility-on-demand-system in a "real world laboratory" set up in Schorndorf, Germany. This paper addresses the following questions: (1) How can stakeholders be involved in the research and development process and become co-designers? (2) What are the suitable ways of supporting and facilitating interdisciplinary exchange and joint work at different places? The main contribution of this paper is the description of a methodological approach. It thereby reflects on the process of inter- and transdisciplinary work in the development phase and pilot operation. In addition, a joint working document, a so called "Specification Book", is utilized to facilitate teamwork and enable the exchange of scientific knowledge within the team. The experiences in the project are also reflected upon and specific recommendations are determined. The paper further reflects on the possibilities and challenges of the methodology and provides recommendations for its application. The originality of the paper lies in its description and reflection of a method that goes beyond the participation of users in the design phase of the project.
\end{abstract}

Keywords: co-creation; interdisciplinary; transdisciplinary; real-world laboratory; participation; sustainable transport; future mobility concepts; mobility-on-demand-systems; ride pooling

\section{Introduction}

The discussion on new mobility concepts is usually carried out from a very technical perspective [1,2]. However, when dealing with complex transformation processes of socio-technical systems, like the transport system, we are not only confronted with technical challenges but also with questions of user acceptance, which include the users' willingness and ability to change long established behavioral patterns [3,4].

Fundamental changes of behavioral patterns are however essential for reaching sustainability goals for mitigating climate change. Sustainability is evaluated by factors such as usability or economic issues for example, depending on the different fields, for this reason experts from various disciplines should be involved in the research process. "As has been well-known for more than two decades, sustainability research must be highly inter- and transdisciplinary [for definition see Section 2.3] in nature in order to respond to the challenges inherent to the topic. Sustainability research should provide knowledge for action and is therefore profoundly related with social and political issues such as regulation, behavior, value-added chains, daily routines of users, consumption patterns, economic incentives, perceptions, attitudes and values" [5]. 
Besides the need for interdisciplinarity in the development of sustainable products and services, new solutions should be developed and co-created by those who use it. Brake et al. [6] suggested that "more successful flexible transport services are likely to be achieved by the "bottom up" approach of consultation over a wide area, leading to substantial adjustments to the network of transport services". Accordingly, the early involvement of users and additional stakeholders might facilitate the development of systems that fulfil user needs, as well as strengthen users' willingness to change and adapt to technical progress [7].

In order to create and develop sustainable mobility services it is crucial to study prospective users' behavior and the underlying mechanisms of decision processes. As Csikszentmihalyi [3] outlines: "To provide a more complete view of what human behavior and experience entail, it is necessary to begin observing what people do and what happens to them when they are not confined to the couch or the laboratory, but are involved in their normal lives in real ecological settings". Accordingly, Rau et al. [8] state that science is often required by research funders to produce "societally relevant and 'usable' knowledge and to actively engage with non-academic actors".

In view of the fact that sustainability research is frequently tasked with developing concrete solutions to socio-environmental problems, that can be directly implemented [8], this paper offers an experimental approach for the development and testing of a mobility-on-demand system (for a definition see Section 2.2) in a real-world laboratory that allows observation of the transformation in a real context rather than only on paper (for a definition see Section 2.3). The main goal of the research project real-world laboratory Schorndorf presented here, is the development of a flexible bus system for the city of Schorndorf that addresses the needs of different user groups and the demands of various stakeholders. The real-life testing environment of the newly developed on-demand bus system was, as the project name suggests, the city of Schorndorf, which is a medium-sized major district town with a population of approximately 40,000. Schorndorf is situated $25 \mathrm{~km}$ east of Stuttgart (for more information about Schorndorf see Section 4.1).

The goal of this paper is the description of a methodological approach in developing new, sustainable mobility systems. Using the research project real-world laboratory Schorndorf' as an empirical case study, the bus system we developed is briefly presented and possibilities and challenges of applying the methodology are discussed. The real world laboratory is characterised by an experimental approach which is used to initiate and accompany the transition process of the existing public transport system into a new transport system. This paper focuses on two main research questions.

First, the paper aims to answer the question: "How can stakeholders be involved in the research and development process of a new mobility concept and become co-designers?" To develop a demand-driven mobility service that meets the requirements of different users, some of whom have special needs, it is necessary to find new approaches, different from those that have dominated conventional transport research in the past. This requires the further development and testing of (combinations of) methods [9] that result in demand-driven solutions based on the collaboration between people with scientific backgrounds as well as people without. This paper aims to demonstrate the added value of participatory methods and how knowledge of general public can be successfully integrated into new mobility concepts in order to create and operate services that are ecological while being both economically and socially sustainable and user-friendly.

Second, the following research question is addressed: "What are suitable ways to support and facilitate transdisciplinary exchange and joint work in different places?" Given that transdisciplinary projects are highly dynamic, and new insights and results are generated throughout the project, research results and the process of derivation should be continuously documented and shared to ensure the plausibility and transparency of the results. Traditional tools for facilitating interdisciplinary work might not be suitable to meet the challenges posed by transdisciplinary research projects, i.e., having to integrate knowledge from different academic disciplines with practical knowledge. Thus, the agreement on a common language and the acknowledgement of distinct norms, values, and methodologies of different disciplines is a crucial challenge to overcome [10]. 
There are only several empirical findings on the factors that contribute to an efficient and successful collaboration between academic researchers [11,12], but few concerning the collaboration within transdisciplinary teams [4]. Thus, the paper aims to define suitable tools to support the exchange within a transdisciplinary team.

After presenting definitions and the state of the art of sustainability research concerning mobility and inter- and transdisciplinary approaches in Section 2, the combination of methods that were developed is described in Section 3. In Section 4, the characteristics of the newly developed on-demand bus system are presented and the application of the method in the real-world laboratory Schorndorf is demonstrated. In the discussion, the potential and challenges of applying the transdisciplinary approach to the development of a new mobility concept are presented in Section 5. Lastly, a short conclusion is given in Section 6.

\section{Theoretical Underpinnings: The Transdisciplinary Development of a New Sustainable Mobility System}

Sustainability research and inter- and transdisciplinarity are highly interconnected, as reflected by the observation that "Governments [and] funding agencies [... ] have all arrived at a near consensus that development cannot be sustainable and long-lasting unless people's participation is made central to the development process" [13]. Real-world-laboratories often go hand in hand with the objective of facilitating sustainable transformative processes [14,15].

Before demonstrating the value of applying a transdisciplinary, user-centered approach to the development of sustainable mobility systems, the three main thematic areas of this paper are introduced: sustainability (Section 2.1), mobility-on-demand-systems (Section 2.2) and inter- and transdisciplinary approaches in transport science (Section 2.3).

\subsection{Sustainability}

Real-world laboratories promise a contribution to the understanding and facilitation of societal transformation towards sustainability $[16,17]$. As such, real-world laboratories have recently caused interest among many researchers in different fields of sustainability such as sustainable living [18,19], energy efficiency [17] and sustainable urban development [14] amongst others. Sustainable development always encompasses two perspectives: the results and the process [20]. For the present case study, sustainability is the objective for both the new public transport system and the real-world laboratory approach.

Sustainable transport is defined as a transport solution that is accepted by a majority of the population [21]. The Sustainable Urban Mobility Plan (SUMP) asserts a transport system to be sustainable if it reduces noise pollution and greenhouse gas emissions, enhances the quality of life, is accessible to all user groups and optimizes efficiency and cost effectiveness among others [22]. Richardson [23] derives a definition from the Brundtland Commission's definition of planet-wide sustainability as "the ability to meet today's transportation needs without compromising the ability of future generations to meet their transportation needs". This paper utilizes Richardson's definition [23].

Since " ... problems related to sustainability are usually complex, ambiguous and multi-dimensional, thus generally precluding the existence of simple solutions" [24], a transdisciplinary development process could contribute to achieving the aims of creating sustainable outcomes. A sustainable development process is defined as a development process that "meets the needs of the present without compromising the ability of future generations to meet their own needs" [25]. Sustainable development is said to have three dimensions: environmental, economic and social [26].

\subsection{Mobility-On-Demand-Systems as Sustainable Transport Services}

The rapid dissemination of on-demand ride services marks a transformation of urban mobility [27]. The emergence of new mobility providers like Uber, Lyft and Via is driven by the prospect of new business segments based on travelers' demand for higher flexibility and enabled by 
the progress in digitalization and the provision of real-time information [28]. The concept of mobility-on-demand-systems meets the requirements of a society that strives for personalization and flexibility. Mobility services operate in a demand-oriented way that adapts the route and schedule to the actual demands of users [29]. An increasing body of empirical evidence indicates that mobility-on-demand services can provide numerous benefits for transportation efficacy, users' satisfaction and the environment [28,30-32]. When serving as a feeder to transit lines for public transport, mobility-on-demand-systems can contribute to resolving the challenge of the first and last mile by providing seamless and comfortable travel connections and thus facilitating intermodal trips [30]. The mobility-on-demand-systems that match users' ride requests through ride-sharing schemes are regarded as being especially sustainable because they reduce emissions by pooling rides and increasing the occupancy rate of vehicles [33]. See also Liyanage et al. [27] for a review on the proven and presumed technological, social, ecological, and economic impacts of mobility-on-demand-systems.

The discontinuation of services like Kutsuplus that operated as a pilot in Helsinki, Finland from 2012 to 2015 proves that accompanying research is needed to assess the needs of all stakeholders and take them into account in the development phase of a service [34]. This is especially relevant due to the multidimensional and interdependent factors that determine the success of a service. A study by Jokinen et al. [34] evaluated the on-demand bus service and recommended looking beyond long-term financial sustainability and taking into account a range of other critical factors such as the decision-making process. Learning from the challenges experienced by the Kutsuplus service, Jokinen et al. [34] identified a comprehensive planning process that facilitates the management of multidimensional factors for success. They recommend a multidisciplinary team with versatile expertise and skills to work together to account for the complexity of a new service [34]. The evaluation of the Kutsuplus services revealed the need for more adaptive and agile decision-making processes and an increase transparency. In addition, recent studies have shown that users' evaluation and acceptance of technological innovations are bound to their current behavior and how people ascribe meaning to their travel behavior [31-33]. Thus, when introducing new mobility-on-demand-systems to the market, travelers' preferences and needs must be considered early in the development process to ensure user acceptance and willingness to use the new service [35].

\subsection{Inter-and Transdisciplinary Approaches in Transport Science}

The equal integration of people from different disciplines and members of the public requires further development and testing of research methods [36,37]. This would allow an understanding of social-technical systems like mobility, and assist in the development of needs-based solutions co-designed by members of the public. According to the states of the framework for Responsible Innovation, people in the innovation process should be mutually responsive to each other and strive for a bottom-up-policy; including members of the wider public, and appreciate the quality of dialogue between different stakeholders as a learning exercise [38]. Hessels et al. [4] add to this position by suggesting that people without a scientific background should be involved in research and development, which is defined as transdisciplinarity: "There is wide agreement about the importance of transdisciplinary research to address complex sustainability issues" and the merits of participation [13,39], although the "paradoxes of participation" [40] are also discussed critically in the literature [40,41].

There are a variety of definitions for transdisciplinary research [42,43]. Reflecting this wide variety of definitions, transdisciplinary research is understood in this paper as a user-oriented variant of interdisciplinary research focused on synthesis [44]. This means opening up research towards (a) everyday life problems, (b) the integration of non-scientific actors, and (c) the explicit normative processing of their issues $[45,46]$. Due to this, the research questions, hypotheses, methods, and language of this research $[47,48]$ are different to the research that does not involve non-scientific actors (for discourse, see also [49-52]). 
One format of transformative and transdisciplinary research is the real-world laboratory approach (for more information on real-world laboratories, see [53-55]. Real-world laboratories have gained increasing popularity in the recent years [56]. They promise a contribution to "the understanding and facilitation of societal transformation towards sustainability" [56]. The research format represents a social context in which "real experiments" are carried out to learn about social dynamics. The idea of a real-world laboratory thus transfers the concept of a scientific laboratory to analyze social and political processes in 'the real world' [55,57]. Real-world laboratories create spaces for transdisciplinary research, where science and society cooperate, and mutual learning can occur in an experimental environment. [55,58]. Real-world laboratories are "open-innovation environments typically characterized by private-public partnerships (research institutions, industry, SMEs) aimed at implementing and demonstrating new services, products and systems for urban applications" [59]. It is important to emphasize that, unlike scientific experiments, where the focus is on causal knowledge produced in a fully controlled lab setting, experiments in real-world laboratories produce transformational knowledge and take place in settings that are not controlled $[17,60]$. Usually, these types of laboratories are a catalyst for the process of sustainable transformation and therefore gain increasing popularity, as Schäpke et al. [61] state: "There is a strong trend towards research in society-based laboratories, especially in relation to sustainability."

The new role of science in transdisciplinary research is led by the objective of developing robust solutions for sustainable transitions through mutual learning via the empowerment of stakeholders and enabling citizens to serve as co-creators [62].

There is a distinction between co-creation, co-production and co-design, but the terms are often used interchangeably [63]. Co-Creation can be considered a broad 'umbrella' term that refers to co-creation as an act of collective creativity that is experienced and performed jointly by a group of people $[63,64]$. This term includes co-design and co-production and is used in the following section to describe an approach to creating a solution by integrating scientific and non-scientific perspectives. In mobility projects, such as the City of Bremen traffic development plan [65], members of the public were included as participants and decision makers, placing importance on the undervalued knowledge of laymen [66]. At the same time, the role of stakeholders particularly members of the public and their willingness to participate in laboratories is not known and defined [67-69]. Often a high degree of participation is emphasized as important [70,71], but only a few studies analyze the level of participation and the methods used to involve users and citizens in laboratories [72]. Moreover, there is a lack of empirical and comparative studies that focus on the added value of laboratories $[17,73]$.

\section{A Methodological Transdisciplinary Approach to Develop a User-Centered Mobility-On-Demand-System}

Understanding mobility as a socio-technical phenomenon [9] and developing the appropriate mobility services with members of the public as co-designers requires a transdisciplinary approach as well as the application of modified research methods [74]. For this reason, instead of first generating data about user behavior and preferences and then putting it into practice, a transdisciplinary approach was developed with members of the public to provide a sustainable solution for public transport.

Figure 1 illustrates the newly developed methodological approach. It shows the cycle from (1) analyzing the behavior of potential users (2) over to the identification of user groups and possible use of the new system (3) to the generating of ideas and concepts and (4) lastly testing and evaluating the new system. This procedure was named "Transdisciplinary Development of Socio-technical Systems" (the TraSy method). In the following sections, the application of the newly developed method is demonstrated through the example of the real-world laboratory Schorndorf. The goal was to develop a procedure that can also be used in other contexts to develop socio-technical systems. For a very detailed description of this method see Gebhardt et al. [75]. 


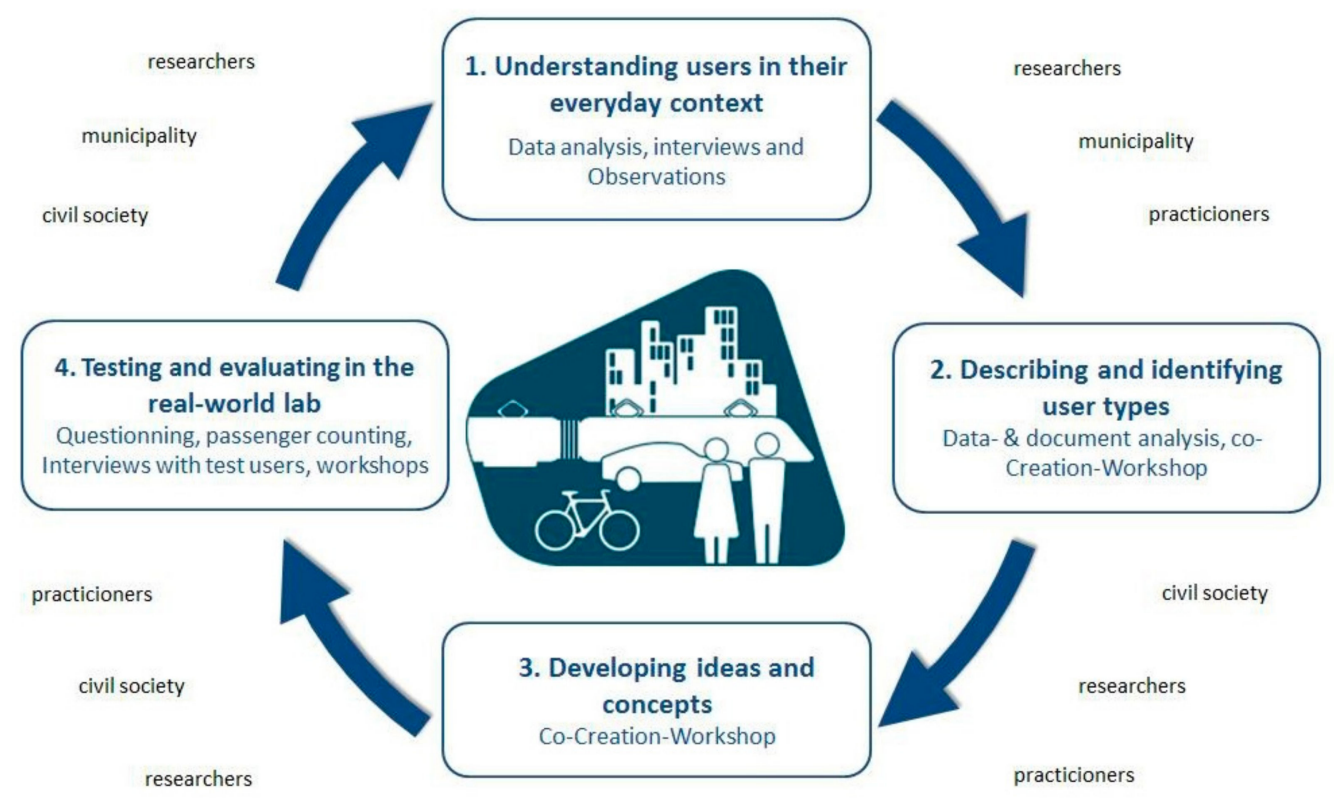

Figure 1. Schematic representation of the user-centered procedure and the participants in the respective phases as used in the TraSy method (C) adapted from Gebhardt et al. [75].

The empirically based participation approach of the TraSy method is more comprehensive than similar methods, such as methods of participatory technology assessment (pTA), which seek to involve stakeholders and interested parties in socio-technical and political decision-making processes [76]. The pTA focuses on the evaluation of technical developments in order to support decisions [77], while the TraSy method's goal is the development of a new system in cooperation with its potential users. In contrast to the pTA, the TraSy method involves users and public stakeholders including employees of the public transport sector (e.g., bus drivers) and scientists.

Similarities between the approaches of participatory technology development [78] and the TraSy method can be seen in the iterative approach and the symmetrical relationship between the scientists and the future users, who are seen as equal research subjects and not as objects of research $[79,80]$. However, the TraSy method goes beyond the participation of users in the design phase. A range of potential users of the new system are involved in all phases of system development from concept to implementation and use of an innovation [81].

The TraSy method aims to involve users in the development phase of new products, by following an iterative experiential design process that uses recurring slopes of exploration, co-creation, and evaluation. This means that individual components of the system may be updated in several iterations or the whole cycle (see Figure 1) can be repeated to form the final product. Furthermore, unlike other approaches, experimentation and evaluation are driven by users within a real-life context and not in an artificial setting. In contrast to Design Thinking that focuses mainly on the idea generation according to the five phases of (re)defining the problem, need finding and benchmarking, ideating, building and testing [82], the TraSy method also addressed the testing and evaluation in the real-world context (see step 4 of Figure 1). Lastly, as another unique feature, the TraSy method bases the development phase on a comprehensive analysis of secondary data concerning the status quo in the specific context (e.g., data concerning commuter mobility).

\subsection{Data Collection}

The starting point of developing a new on-demand bus system was the investigation of the status quo in Schorndorf. The context of everyday life was investigated by analyzing the socio-demographic data, settlement structure, mobility behavior and available mobility offers (step 1). Apart from the analysis of data and documents in the beginning, it was indispensable to apply qualitative and 
explorative methods to reveal the intrinsic motivation of the individual, that determines action but is hidden behind visible behavior [83,84]. Knowing that people perceive and generate mobility according to conditions in their daily lives, [85-88] qualitative methods are essential in helping investigate individual mobility $[2,89]$.

Data analysis, 12 expert interviews with local stakeholders (bus operators, taxi drivers, bus drivers, responsible authorities, etc.) and two workshops, with around 20 members of the public and local associations, helped to identify and describe potential user groups and their mobility requirements (step 2). Members of the public were selected based on representation of the make-up of current bus users as well as some car users as potential future users. Participants were addressed via several communication channels (e.g., addressing them personally in public space, through social media or mail, and advertisements in the local newspaper).

In two co-creation workshops scientists with different backgrounds and people without a science background (around 20 citizens as representatives of the defined user groups), as well as $3-4$ practitioners (such as the bus operator and representatives of the municipality), were brought together to develop and specify the mobility concept in a playful way (step 3). Visual elements were used to create ideas of what a new mobility concept could look like and to enable joint work with members of the public and scientists from different disciplines. For example, the workshop participants sketched out a typical trip (e.g., going shopping) and discussed what this trip would ideally look like with the new bus. Handicrafts and drawings helped to facilitate communication and cooperation in these heterogeneous work environments. Questions that were discussed within the workshops are useful in exploring what factors to include in the development of demand-driven and user-specific solutions. To avoid only selective interests from being introduced into the development process (as happens in many participation processes), the team was cautious not to only take on middle-class, male persons without a migrant background [90-92]. These groups are very often over-represented in participation processes (see also Section 5.2). Considering this, efforts were made to address older and mobility-impaired people. The participants were informed about their rights in advance and gave their consent to the project team by signing a consent form. The integration of user feedback was used to optimize the general bus system layout, the routing algorithm, the smartphone app, and the bus driver navigation app.

In the final phase (step 4), the newly developed bus system was tested for nine months (March 2018-December 2018) under real-world conditions in Schorndorf. The tests were evaluated by passenger counting, statistical analysis of collected (booking) data, participatory observation while using the bus, quantitative surveys at two points in time (May 2018 with $n=174$ and October 2018 with $n=105$ ), and qualitative interviews with 11 selected test users at four time points (May, October, December 2018, and July 2019). The investigations at several time points aimed to examine potential changes in the behavior or assessment of the users. Questionnaires were available in all buses as well as in the town hall, and several cafés. The number of people who answered the questionnaire is satisfactory considering the number of regular passengers who use busses in Schorndorf. The respondents are also representative of the age and gender distribution of passengers in a small-town context. In the survey, open and closed questions about current mobility behavior, socio-demographic aspects, as well as questions regarding the assessment of the new system, were asked. The extent of participation in the development and testing process was also asked about. The 11 test users are comprised of different age groups, with a surplus of elderly people above 65 years, as this is the largest bus user group in Schorndorf.

Continuous communication with the test users allowed an understanding of the user perspective and an improvement of the system based on the users' needs. Test users were also selected via several communication channels (e.g., personal addresses in public space, social media, and advertisements). 


\subsection{Analysis and Data Preparation by Using the Transdisciplinary Work Tool "Specification Book"}

The analysis, structuring and interpretation of the collected qualitative data followed the principles of "Grounded Theory" [93-95]. The analysis resulted inter alia in the outline of different use cases and bus system requirements (e.g., operating hours). Visual elements, such as drawings and hand-made prototypes, which were part of the results of the workshops, were part of the analysis and discussion. In accordance with the principles of a mixed-methods approach, various types of data were combined for the development process and for the evaluation of the bus system. This proved to be valuable to compensate for the limitations of certain data formats and for gaining an in-depth insight into system requirements, performance during the test phase and user acceptance.

Through continual optimization, a "Specification Book" provided structure for all the data collected (quantitative-statistical data, passenger counting, qualitative data from the interviews, and workshops) and for the system parameters that were derived during the process. This documentation format addresses the challenges of inter- and transdisciplinary exchange, analysis, and teamwork by providing knowledge from different academic disciplines in a comprehensible way to the entire project team in all project phases. The Specification Book comprises a glossary with definitions of terms that are used differently in different scientific context or are not common knowledge for some disciplines. Technical system functionalities and parameters are explained in non-technical language. The specifications thus enable researchers with a social science background to understand engineering colleagues' technical terminology and vice versa. The Specification Book represents a further development of the traditional requirement specifications and project statements of classical project management $[96,97]$ for use in more agile contexts. It meets the requirements of system development including technical detail solutions in a highly dynamic process. The Specification Book also serves various other functions, for example, to document the derivation and justification of the parameter specification. In order to support team work, the document is accessible to all project partners (read and write).

\section{Results}

This section provides information about the specifications of the mobility-on-demand-system of the real-world-laboratory Schorndorf, focusing on those aspects that were derived from the participatory process. The TraSy method presented in this paper (see Section 3) was developed and simultaneously applied in order to obtain an on-demand bus-system that fulfils user requirements without neglecting sustainability aspects.

\subsection{Information on the On-Demand Bus System from the Real-World Laboratory Schorndorf}

The bus system intended to close the gap of knowledge about on-demand mobility systems for areas with medium density, e.g., medium-sized cities, which are widespread in Germany. In contrast, similar projects and pilot tests often focus on urban areas with very dense populations or rural areas with very low population density [98]. Schorndorf's structure is typical for the state of Baden-Württemberg which allows us to apply the results gained in the real-world laboratory to other communities [98]. Due to the real-life oriented, experimental nature of transformative science, this new transport system should not be a stand-alone solution but be integrated into the existing transport system [74].

The city of Schorndorf is characterized by a transport system with a public bus system including three inner-city bus lines and a metro line that connects the system to the city of Stuttgart (600,000 inhabitants). Schorndorf is a rather "old city", with a mean age of 51.5 years. Accordingly, the age groups of 45 to 55 years $(\sim 17 \%)$ and 65 to 75 years $(\sim 11 \%)$ represent the largest groups in Schorndorf's society [99]. These age ranges were considered and therefore, unlike many similar mobility-on-demand-systems, the on-demand bus concept aimed to avoid excluding user groups like elderly or impaired citizens. This was implemented by measures such as a telephone booking option [100]. 
Unlike conventional scheduled bus systems, on-demand systems have no fixed routes or timetables. In Schorndorf, a specifically designed routing disposition algorithm processed and combined ride requests to create an optimized route. For detailed information on specification of system requirements including system parameters like operation period, stopping points and routing (disposition algorithm) see [98]. Table 1 presents the key parameters of the developed bus transport system of the real-world laboratory Schorndorf, as well as an extract of the results of the pilot operation. Due to the scope of this paper, the presentation of the results is limited to a few selected parameters. Detailed evaluation results of the pilot operation will be published in separate papers.

Table 1. System specification and selected results of the on-demand pilot operation.

\begin{tabular}{|c|c|}
\hline \multicolumn{2}{|c|}{ On-demand system specification } \\
\hline $\begin{array}{l}\text { Operating } \\
\text { principle: }\end{array}$ & Replacement of scheduled bus lines with on-demand bus service; \\
\hline Testing period: & Nine month, from March 2018 to December 2018; \\
\hline Operating time: & $\begin{array}{l}\text { March } 2018 \text { to July 2018: Friday 3:00 p.m.-1:00 a.m. }{ }^{1} \text {, Saturday 6:00 a.m.-Sunday } \\
\text { 1:00 a.m.; } \\
\text { July } 2018 \text { to December 2018: Friday 8:00 p.m.-1:00 a.m., Saturday 1:00 p.m.-Sunday } \\
\text { 1:00 a.m.; }\end{array}$ \\
\hline Operating area: & A $3.4 \mathrm{~km}^{2}$ urban area with a population density of 681 inhabitants per $\mathrm{km}^{2}$; \\
\hline Booking options: & $\begin{array}{l}\text { Smartphone application (see Figure 2), website interface, telephone hotline and local } \\
\text { cooperation } \\
\text { partners (e.g., cafés), no spontaneous boarding, except for passengers at the main } \\
\text { station; }\end{array}$ \\
\hline Pricing: & $\begin{array}{l}\text { Fully integrated into the existing public transport price system; season tickets } \\
\text { accepted; }\end{array}$ \\
\hline Bus stops: & 44 conventional bus stops; more than 200 additional virtual bus stops; \\
\hline Vehicles: & $\begin{array}{l}\text { Barrier-free minibus, model Mercedes-Benz Sprinter City 35, for a maximum of } \\
22 \text { passengers (see Figure 3); } \\
\text { Minibus, model Mercedes-Benz Sprinter 313CDI (modified with a hybrid drive) for } \\
\text { a maximum of } 8 \text { passengers; } \\
\text { Barrier-free City bus, model Mercedes-Benz Citaro (solo bus), with a capacity of } \\
\text { approximately } 100 \text { passengers; } \\
\text { Maximum of two vehicles operating in parallel; }\end{array}$ \\
\hline \multicolumn{2}{|c|}{ Selected results of the pilot operation } \\
\hline Passenger numbers: & More than 10,000 passengers (39 weekends including Friday afternoons/evenings); \\
\hline Vehicle kilometres: & $\begin{array}{l}\text { more than } 20,000 \text { kilometres ( } 10 \% \text { less than in the comparable scheduled bus } \\
\text { operation); }\end{array}$ \\
\hline Fuel consumption: & $\begin{array}{l}\text { Approximately } 60 \% \text { less than in comparable scheduled bus operation due to smaller, } \\
\text { more efficient vehicles and a reduction of driven kilometres. }\end{array}$ \\
\hline Booking media: & $\begin{array}{l}\sim 65 \% \text { via smartphone app } \\
\sim 33 \% \text { via telephone, including booking via cooperation partners; } \\
\sim 2 \% \text { via web interface. }\end{array}$ \\
\hline
\end{tabular}

${ }^{1}$ All time indications "1:00 a.m." refer to the preceding day of operation. 


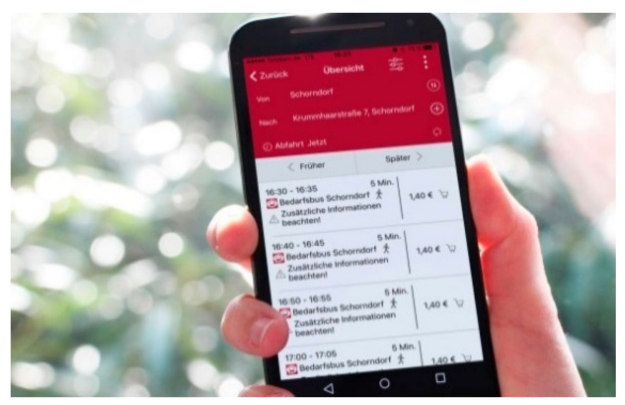

Figure 2. Smartphone App for booking the bus (C) DLR.

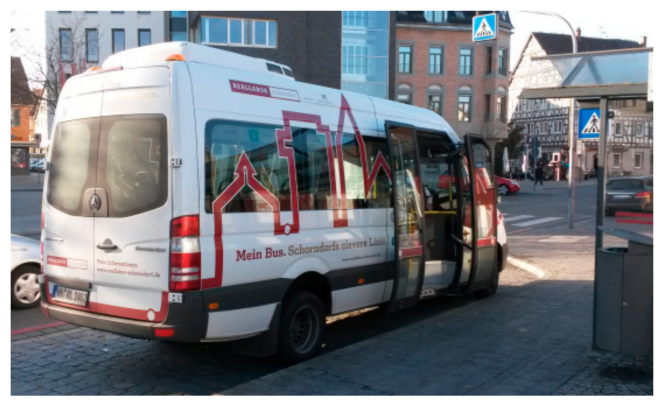

Figure 3. One of the buses that operated the on-demand bus system (barrier-free Minibus) (C) DLR.

\subsection{Applying the TraSy Method to Derive the Bus System Parameters}

The project objectives of the real-world laboratory Schorndorf included the development of a product (a flexible on-demand bus system) and the development of a methodology. Beyond the context of the real-world-laboratory Schorndorf, the TraSy method (see Section 3) may help to optimize similar research and development projects in various fields like infrastructure or education. This section describes the benefits of applying the TraSy method by showing its impact on the design of the on-demand bus system in Schorndorf. It also demonstrates the limits of participation and suggests how to manage the restraints.

Wherever possible, the system parameters of the on-demand operation concept were derived with involvement of the general public and workers. Input of all groups was continuously collected via mail, in discussion, workshops and further communication formats. The information gathered was logically structured, analyzed, and classified by importance and implementation potential within a matrix that was available for the whole project team. The bus system was continuously adjusted according to the input received by general public and workers. This was done, for example, for the operation area and operating times, two fundamental properties of the bus system. Another example is the selection procedure of the booking options, which led to a variety of options including digital and conventional telephone booking, considering the special needs of different user groups. Both the telephone hotline and cooperation with local partners for bus booking were initially not intended but were a result of civil society participation and the requirements of the municipality. Telephone booking proved to be essential for system access, but provoked considerable challenges for system optimization. Evaluation of the pilot operation via quantitative surveys (see Section 3.1) reveals a high share of telephone booking for passengers aged over 55. This result highlights the differences in user preferences. The general share of smartphone application booking is significantly higher at $65 \%$ according to digital system data.

The high share of fixed telephone booking for elderly passengers (low share for entire user group) was not a surprising result of the pilot operation. It is a known fact that smartphone usage is not widespread among some parts of the population. However, it was due to the participatory process that this fact was actually considered when specifying the on-demand system. It became evident that participatory processes not only generate knowledge about users' needs but also give greater weight to them, thereby ensuring practical application. Many on-demand systems decide not to offer telephone 
booking not due to lack of awareness of users' needs, but due to strategic decisions with regard to their business model (costs, target profit, target groups) and also due to unfavorable route optimization constraints that are related to telephone booking. Some user requirements significantly influence the performance and cost of on-demand systems. Telephone booking was one of the main items of the on-demand pilot's operational costs compared to scheduled buses in Schorndorf.

In contrast to other participatory approaches that only integrate civil society to derive system requirements and generate conceptual ideas during the product development phase, the TraSy method extends participation to the testing, evaluation and optimization of a product. Within the real-world-laboratory Schorndorf practice actors were not only involved in defining the on-demand system in order to prepare the pilot operation but also user feedback was continuously collected and integrated into a structured workflow during the complete pilot phase. The civil society together with the on-site project team's experience led to appropriate system changes if those changes were evaluated as reasonable and feasible. The TraSy method does not only support derivation of specific requirements and parameters, but also enables the implementation of a trust-based relationship between actors from commercial enterprises, municipal administration, civil society and science. Test users stated in interviews that they appreciated being part of the research team. Subliminal fears, especially of elderly passengers, could be revealed and addressed in a constructive dialogue. Also the bus drivers emphasized that they valued the possibility of shaping the system together with project team members instead of executing tasks that were defined merely academically without practical focus. The mutual trust of drivers and core project team led to a positive and solution oriented attitude of the drivers and thus resulted in many solutions for problems with practical details on-site. One example is the management of passengers without having booked boarding at the main station, which was resolved by the drivers through active communication.

One result of the ongoing transdisciplinary exchange was the reduction of operating hours from Friday evening to Sunday night, excluding Friday afternoon and Saturday morning. The necessity for a dialogue with all stakeholders became obvious based on user feedback and the observation of researchers on the buses. Opinions on the adjustment of operating hours were not unanimous in Schorndorf. Hence, the decision to adjust the operating hours was a result of a workshop consisting of participants with diverse backgrounds supporting and opposing reduced operating hours.

Finally, reduced operating times were decided, considering user feedback and experiences within the first months of testing. During certain time spans (Friday afternoon, Saturday morning), regular users like commuters and passengers shopping at the weekly farmers market were not satisfied with the need to book the bus in advance. Additionally, the on-demand system proved to be less suitable for the high volume of passengers on Friday afternoons. Supported by transparent communication and comprehensible explanation of the reasons for changing the operating hours, acceptance was obtained from most of stakeholders involved. The reduction of operating hours was not perceived as a setback, but the response from civil society showed that flexibility and consideration of user feedback were understood as advantages of this research format.

Our findings and experiences let us assume—as postulated by Mitchell [101] — that the early and continuous participation of citizens has advantages. The scientists learned from users what to improve in the system. In addition, the results of the surveys showed that people who were involved in the development of the new bus system or actively tested the bus, evaluated the new system more positively than residents who did not participate. A test user described how the benefits of the new system directly related to his participation in the project: "The benefit is the flexibility and that it actually goes faster, and I find it very positive that I take part in the real-world laboratory and can participate in pioneering forms of transport" (Test user Mrs. A; 62 years old, May 2018).

\subsection{The Specification Book as a Tool for Inter-and Transdisciplinary Research}

The Specification Book (see Section 3.2), as an information sharing platform for inter- and transdisciplinary teams, proved to be a useful tool in the real-world laboratory Schorndorf. It represents 
a compendium of all the information needed to develop the bus service e.g., information on legal aspects, system parameters and state of the art solutions. It contains all the system requirements that are determined over the entire duration of the project with the help of the transdisciplinary process.

Throughout the project, the Specification Book was constantly updated with additional information. The results showed that a shared document with a thematic structure functioned much better than chronologically structured meeting minutes in documenting decisions on system layout and providing quick access to relevant data on specific topics. The justification of decisions and their chronological sequence were documented and organized by the thematic structure of the document. This meant that the document was essential for the interdisciplinary work in the team, particularly regarding work that took place at different locations without regular face-to-face meetings. It allowed exchange of information both about meetings with the complete project team and about bilateral agreements. The Specification Book supported structured and fact-based discussions of relevant topics, such as the reduction of the operating hours of the mobility-on-demand-system according to the feedback of users [35].

To sum up, the Specification Book was used to solve the following challenges of transdisciplinary work in the real-world-laboratory Schorndorf research project:

- developing a common language between the different disciplines;

- collecting and sharing the generated knowledge "in real-time" (especially about the acquired system requirements);

- continuously documenting the process of parameter specification and specifying the reasons for the deriving of specifications;

- facilitating the information exchange within a team whose members work in distributed places;

- "translating" findings of qualitative methods into specific requirements and technical specifications;

- promoting discourse between the experts involved;

- meeting the challenges of a highly dynamic process of the development and refinement of the system requirements;

- commissioning of sub-tasks, like software programming.

\subsection{Novelty/Originality and Scientific Merit of the Research Presented}

Though extensive approaches for participatory methods and transdisciplinary collaboration exist, the real-world-laboratory Schorndorf used its own specific set of methods and the Specification Book as a tool to ensure the effective utilization of available resources [39]. In Schorndorf, the implementation of a new mobility solution was particularly challenging, as an existing available mobility (conventional scheduled inner-city bus lines) was replaced by a product developed within the project (an on-demand bus service).

As the on-demand bus service was no complementary system, but a replacement of existing bus lines, a heterogeneous user group was affected by the real-world experiment. This meant that, in contrast to some projects that only receive input from already engaged and highly educated local experts, participants in Schorndorf came from diverse educational and social backgrounds, including mentally or physically impaired persons as well as retired transport planners with expert knowledge on mobility systems.

The requirements of public transport users vary extensively (based on factors like age, attitude, preferences, and education), they also have conflicting objectives. For example, some residents want the bus to drive as seldom as possible through their residential area due to noise emissions whereas bus users are interested in a regular schedule. Accordingly, system design is based on finding an acceptable compromise between customer requirements, ecological goals and economic constraints. The newly developed TraSy method helps address these conflicts and supports the development, testing, and evaluation phases. The method includes extensive communication between test users and the project team, including bus drivers as practical system experts. To avoid subjective 
interpretations of the findings a combination of the methods (described in Section 3.1) were used as well as collaboration of various scientific disciplines to achieve a more objective result. As expected, findings from the quantitative surveys showed that offering heterogeneous user groups a replacement bus system is challenging, as acceptance of the new flexible system was highly dependent on age for the pilot operation. Around $50 \%$ of young adults surveyed were satisfied with the new system, whereas only $25 \%$ of people over 50 years of age ticked satisfied in the questionnaire.

Replacing existing conventional bus lines instead of complementing them, with an on-demand system proved to be challenging. The main challenging aspect is meeting the requirements of heterogeneous user groups with persistent mobility routines. However, the replacement of bus lines offers possible economic and ecological advantages (see Table 1). In addition, positive health implications were recognized by members of the public, such as reduced noise exposure.

\section{Discussion}

The measurement of the success of a project and the assessment of its impact pose large challenges. This is especially true for long-term sustainability projects, as their impact assessments are based on largely hidden impacts, like possible shifts in opinion and the behavior of individuals [8]. In the following section, the potential and challenges of the proposed methodology are reflected upon, and recommendations are extrapolated. As real and sustainable transformation requires time, the long-time effects of the new bus system could not be assessed within the time-frame of the project. Thus, the following reflection is restricted to the methodological approach.

\subsection{Potential of the Proposed Approach}

The potential can be clustered into four categories: (1) Understanding and observation of social dynamics and transformational processes, (2) establishing synergy through the integration of different disciplines, (3) enhancement of members of the public's acceptance of new services and products, (4) activation and empowerment of the innovative potential of members of the public. Scholz et al. [16] previously proposed the benefits of a trans-disciplinary approach to bring together scientific scholars with scholars from seemingly unrelated disciplines and as well as people without a science background. We share Kumar's [17] opinion that the knowledge of local residents is equally as important and valuable as that of scientists'. The proposed real-world laboratory approach serves to "overcome the reductionist view of science" [12]. Real-world laboratories prove beneficial in studying transformational processes in real settings, and as such have been called an 'ideal-type' of transformative research [61].

The Specification Book described in Section 3 facilitated a transparent documentation of the decision-making process and further illustrated the influence of the participation of members of the public and other stakeholders in the development process. The Specification Book represents a tool for internal use only, so an informal style can be used, which ensures fast and easy information exchange. Furthermore, the proposed methodological procedure (see Figure 1) proved to be powerful in stimulating the actors to look beyond the confines of their own disciplines and develop mutual understanding and respect.

Studies show that the users' assessment and acceptance of technological innovations are bound to their current behavior [87,102]. The experiences of the real-world laboratory Schorndorf confirm this assessment and show that involvement affects evaluation and acceptance. As shown before, the involvement of local people generated a sense of ownership and personal consternation, which is seen as an essential prerequisite for the sustainability of interventions [13]. In light of our experience, it can be concluded that early involvement of the public increases the acceptance of a newly developed product or service. In addition, the innovative potential of a society can be encouraged by applying this kind of transdisciplinary approach. Even in the case of the newly-developed products not being successful, this approach allows one to think ahead of social negotiation processes and to elaborate on model solutions. Furthermore, this process allows one to experience and understand social dynamics 
in complex socio-technical systems. These findings should encourage urban and transport planning to pay more attention to the benefit of early and continuous participation of the population [6].

\subsection{Challenges of the Proposed Method}

Several challenges and drawbacks have to be considered when applying transdisciplinary research methods to the field of sustainable transport. These challenges can be clustered into four levels: (1) The cognitive-epistemic level, (2) the social and organizational level, (3) the communication level, and (4) the factual-technical level.

At the cognitive-epistemic level, a common understanding within the team was a key challenge within the transdisciplinary project, especially at the beginning. The recognition and appreciation of knowledge and methods of other disciplines as well as the knowledge of the general public, was a challenging goal over the entire duration of the project. As mentioned before by Parodi et al. [103] a common understanding of the real-world laboratory approach is essential for securing a shared identity of different actors.

At a social and organizational level, the social bias in the process of selection must be considered. In scientific discourse this problem is negotiated under the term "crisis of representation" $[90,104]$. Since participation depends to a great extent on individual resources, participants usually come from a similar socio-economic milieu (middle-class, male, without migration background, aged above average). In contrast, migrants, young people and members of lower income classes are underrepresented [91,92]. Thus, there is a risk that only selective interests will be introduced into the negotiation process [90]. As described by the so-called Matthew effect ("whoever has, will be given"), socio-economically well-off members of society are particularly committed to their own interests, while the interests of resource-poor individuals remain under-represented [105], and certain groups are more difficult to reach than others [72]. Bearing this fact in mind is very important in the recruitment of members of the public. To address this, different communication channels (e.g., information in public space, social media, and networks, letters to a random sample) should be used.

Ethical questions concerning the intended and unintended real-world impact on the lives of citizens and other stakeholders have been raised by other researchers in the context of real-world laboratories [17]. A thoughtful and comprehensive approach that deals with ethical questions is highly recommended. Another challenge at the social and organizational level is the prioritization of diverging interests. While, for a city, a flawlessly functioning system is the main goal, for a researcher, the processes of failure, of negotiation, or even the non-acceptance of the citizens towards innovation, are also very interesting observations and learning processes.

At the communicative level, transdisciplinary projects face several challenges and drawbacks. First, finding a common language within the team that includes the same understanding of the terminology and methods was a challenge that required mutual learning as mentioned in the reflection of other real-world laboratories [16]. The different perspectives of participants from different disciplines within the team of researchers also became evident when deciding on concepts, methodologies, and working methods. The presented Specification Book (see Sections 3.2 and 4.3) proved to be a useful tool to facilitate the joint work of the transdisciplinary team.

The efforts (and costs) of communication, organization, and evaluation are high for participatory processes and should be considered accordingly in the planning phase of a project as already proposed by [103].

At the factual-technical level, this approach faces the challenge of translating 'soft' and qualitative findings into 'hard' technical system requirements. The design and development of a system that meets all relevant stakeholder requirements, on the one hand, and represents a functional, sustainable, and efficient system, on the other hand, is challenging. Trade-offs should be made carefully and communicated transparently to all persons concerned.

Many of the participant's requests throughout the project cannot, or can only partly, be implemented due to budget or time constraints, which are mentioned as severe challenges for 
the study of long-term transformative processes [103]. An example of limitations was the lack of design of the smartphone app that did not considered the needs of mentally or visually impaired people. For both groups, the requirements were obtained by interviewing the affected stakeholders, but financial limitations prevented the implementation of adequate measures. It is important to communicate and explain such restrictions transparently in the beginning of the project, as well as during the course of the participation process. Defining the roles of the project team members was also difficult. On the one hand, academic neutrality is required when evaluating an on-demand bus system. On the other hand, a professional advertising campaign could have supported user acceptance and understanding of how to use the new system. The challenge of changing and ambiguous roles has been emphasized before by Schäpke et al. [17].

Finally, the authors would like to emphasize the challenges in evaluating the transdisciplinary method and validating the results in a quantitative way. Research on the empirical validation of participatory and transdisciplinary methods are still lacking [72]. One of the main challenges in the experimental evaluation of this method is the missing control product or group that is essential to derive quantifiable and replicable results. One possible solution to evaluate the methodology would be the comparison of the solution that was developed by using the Trasy method with a solution that was developed and tested without a participatory approach, but with the same or very similar boundary conditions (ceteris paribus). Other research subjects like influencing factors on user acceptance could be evaluated by comparing an experimental group and a control group that did not participate in the transdisciplinary process, which was done before in living lab settings [106]. For this purpose, people living in the real-world laboratory could be randomly split in experimental and control group at the beginning of the project [107]. One first approach to validate real-world labs was presented by [81] who based the evaluation of four real-world labs on the Living Lab Triangle. Furthermore, it should be emphasized that the method was evaluated continuously during the project with the help of the iterative development process based on the reflection of different stakeholders. The additional continuous evaluation of the results was of outermost importance for the successful implementation of the transport service.

\subsection{Recommendations}

The following main recommendations can be derived based on the application of the transdisciplinary approach to the development of the mobility-on-demand-system. Many findings are congruent with results of former studies, which are indicated in the text below. These recommendations could provide support for further projects adapting this approach.

1. Accept and appreciate the character of an explorative experiment. This means being open to any development and results being flexible. Consider that the setting of the real-world laboratory is not a tabula rasa [108] but experimenters must base their research and developments on the existing and highly specific characteristics of the lab.

2. Involve the citizens and local stakeholders as early as possible, ideally to define the problem and/or research question from the beginning (see also [109]).

3. New mobility concepts should address the challenges of providing sustainable solutions by focusing not only on selected user groups ("cherry picking") but by integrating different user groups and local practitioners.

4. Reflect the heterogeneity of society by involving various groups of citizens in the participation process (Mathew effect [105]).

5. Involve the municipality and decision makers to enable the implementation of the innovation and empower people through gaining legitimacy [103] (see also [110]).

6. Using a shared platform or tool (e.g., the presented Specification Book; see Section 3.2) to generate knowledge is important, as is the facilitation of joint work by documenting the process and unifying the knowledge level of the team. 
7. Have the courage to try new things. Even if, for example, the introduction of a functioning and economically profitable system fails, in real experiments, one can learn a great deal from these transformation processes, such as negotiation processes between, and empowerment of, the actors' social dynamics [54,55]. Instead of being intimidated by resistance and the possibility of failures, use the experimental setting as 'test beds' [108] for generating knowledge and experiences in a real-world context. Use the pilot phase to test and experiment.

8. Value confrontation and increased awareness of a topic as a success. Even if no change in behavior can be seen or measured, the process of raising citizens' awareness of questions regarding sustainability itself can be seen as a success. It should be noted that transdisciplinary approaches have an inherent responsibility of raising social awareness on related topics [18].

9. Do not be concerned by resistance to change. Since mobility is deeply shaped by routines, people do not change their behaviors overnight. Transformative processes need time. Within transformative processes, you can learn much about the fears, requirements, and learning abilities of people. Try to consider the concerns of users by using an iterative development process that integrates new insights in the development of the service. If possible, carry out a long pilot phase to facilitate more thorough assessments of the transformative processes [103].

When implementing these practical recommendations, the regional boundary conditions for real experiments must also be considered. Furthermore, routines are not changed overnight, and it takes time to initiate, recognize, and map long-term transformative processes. Only long-term studies could actually measure these processes of change. Most of the current research projects and funding instruments are designed for a limited period of time and thus offer little room for transformation. It is, therefore, important to discuss new formats and forms of transdisciplinary work and to create appropriate framework conditions.

\section{Conclusions}

The main goal of this paper was to present a transdisciplinary methodological approach to developing a new, user-centered mobility concept, and apply it to the real-world-laboratory Schorndorf. The format of a real-world laboratory made it possible for members of the public and other stakeholders to design and test a new mobility system. This format is especially interesting in the context of the need for real changes and transformation since it allows the observation and understanding of social dynamics and transformative processes in socio-technical systems. The approach is promising for studying transformational processes and their barriers. However, behavioral changes towards more sustainable mode choices do not happen in the short term, as routines and habits are persistent. Thus, it is important to support and encourage behavioral changes towards sustainability by involving affected stakeholders and offering a trust-based interaction. The TraSy method supports a solution-oriented cooperation by making participation results promptly perceptible within the testing phase. The mixed method approach allows the practical experience and requirements of users as well as existing scientific knowledge and societal goals to be taken into account. The experiences of the real-world-laboratory make clear that new solutions are not necessarily appreciated by the majority of users. The project team therefore also has the role to carefully balance opposing interests and implement a transparent decision making process. With regard to that, the TraSy method proves to be powerful in informing and guiding members of the public through the process. Regarding the assessment of the effect of implemented innovations, long term studies are necessary to evaluate actual transformative effects. In order to account for all aspects of sustainability, further studies should also include a detailed ecological and economic analysis. Further, the application of the newly developed methodological approach in other local and content related contexts would provide valuable findings.

On a conceptual level, the theoretical framing of real-world-laboratories, including their methods and quality criteria, must be discussed and specified. Further, the consequence of following the two aims that are traditionally rather separated in science- understanding and facilitating change-calls for further research. 
The paper at hand shows that the involvement of practitioners and other local stakeholders is essential to facilitate understanding and implementation of sustainable solutions. The authors would like to invite other researchers to apply the proposed TraSy method to further other fields of research, such as infrastructure projects.

Author Contributions: Conceptualization, L.G., M.B. and A.K.; methodology, L.G., M.B. and A.K.; formal analysis, L.G. and M.B.; investigation, L.G.; writing-original draft preparation, L.G., M.B. and A.K.; writing-review and editing, L.G., M.B. and A.K.; visualization, L.G., M.B. and A.K.; supervision, L.G.; project administration, M.B.; funding acquisition, L.G.

Funding: The project "Bürgerorientierte Optimierung der Leistungsfähigkeit, Effizienz und Attraktivität im Nahverkehr (BOOLEAN)" is one of the real-world laboratories funded by the state of Baden-Württemberg by the Ministry of Science, Research and the Arts.

Acknowledgments: The authors like to thank the city of Schorndorf for the support in the entire project and the implementation of the bus operation. Furthermore, special thanks go to the citizens of Schorndorf, especially the participants involved in the workshops and in test operation.

Conflicts of Interest: The authors declare no conflict of interest.

\section{References}

1. Wilde, M.; Klinger, T. Integrierte Mobilitäts-und Verkehrsforschung: Zwischen Lebenspraxis und Planungspraxis. In Verkehr und Mobilität zwischen Alltagspraxis und Planungstheorie; Wilde, M., Scheiner, J., Gather, M., Neiberger, C., Eds.; Springer: Wiesbaden, Germany, 2017; pp. 5-23.

2. Røe, P.G. Qualitative research on intra-urban travel: An alternative approach. J. Transp. Geogr. 2000, 8, 99-106. [CrossRef]

3. Csikszentmihalyi, M. The flow experience and its significance for human psychology. In Optimal Experience: Psychological Studies of Flow in Consciousness; Csikszentmihalyi, M., Csikszentmihalyi, I.S., Eds.; Cambridge University Press: New York, NY, USA, 1992; pp. 15-35.

4. Hessels, L.; de Jong, S.; Brouwer, S. Collaboration between Heterogeneous Practitioners in Sustainability Research: A Comparative Analysis of Three Transdisciplinary Programmes. Sustainability 2018, 10, 4760. [CrossRef]

5. Grunwald, A. A transdisciplinary approach to the process of socio-technical transformation. In Transdisciplinary Research and Sustainability; Padmanabhan, M., Ed.; Taylor \& Francis Group: Abingdon, UK, 2018; pp. 35-52.

6. Brake, K. Reurbanisierung-Interdependenzen zum Strukturwandel. In Reurbanisierung-Materialität und Diskurs in Deutschland; Brake, K., Urbanczyk, R., Eds.; Springer VS: Wiesbaden, Germany, 2012; pp. 22-33.

7. Verein Deutscher Ingenieure. VDI 7000. Frühe Öffentlichkeitsbeteiligung bei Industrie-und Infrastrukturprojekten; Verein Deutscher Ingenieure: Düsseldorf, Germany, 2015.

8. Rau, H.; Goggins, G.; Fahy, F. From invisibility to impact: Recognising the scientific and societal relevance of interdisciplinary sustainability research. Res. Policy 2018, 47, 266-276. [CrossRef]

9. Fraedrich, E.; Lenz, B. Automated Driving-Individual and Societal Aspects. Transp. Res. Rec. J. Transp. Res. Board Natl. Acad. 2014, 2416, 64-72. [CrossRef]

10. Klein, J.T. Interdisciplinarity: History, Theory, and Practice; Wayne State University Press: Detroit, MI, USA, 1990.

11. Benard, M.; de Cock-Buning, T. Moving from monodisciplinarity towards transdisciplinarity: Insights into the barriers and facilitators that scientists faced. Sci. Public Policy 2014, 41, 720-733. [CrossRef]

12. Scholz, R.W.; Steiner, G. The real type and ideal type of transdisciplinary processes: Part II-What constraints and obstacles do we meet in practice? Sustain. Sci. 2015, 10, 653-671. [CrossRef]

13. Kumar, S. Methods for Community Participation: A Complete Guide for Practitioners; Practical Action Publishing: London, UK, 2002.

14. Evans, J.; Karvonen, A. 'Give me a laboratory and I will lower your carbon footprint!'-Urban laboratories and the governance of low-carbon futures. Int. J. Urban Reg. Res. 2014, 38, 413-430. [CrossRef]

15. Trencher, G.; Bai, X.; Evans, J.; McCormick, K.; Yarime, M. University partnerships for co-designing and co-producing urban sustainability. Glob. Environ. Chang. 2014, 28, 153-165. [CrossRef] 
16. Schapke, N.; Singer-Brodowski, M.; Stelzer, F.; Bergmann, M.; Lang, D.J. Creating space for change: Real-world laboratories for sustainability transformations: The case of Baden-Wurttemberg. Gaia-Ecol. Perspect. Sci. Soc. 2015, 24, 281-284.

17. Schäpke, N.; Stelzer, F.; Bergmann, M.; Lang, D.J. Tentative Theses on Transformative Research in Real-World Laboratories. TATuP Z. Tech. Theor. Prax. 2016, 25, 45-51. [CrossRef]

18. Liedtke, C.; Jolanta Welfens, M.; Rohn, H.; Nordmann, J. LIVING LAB: User-driven innovation for sustainability. Int. J. Sustain. High. Educ. 2012, 13, 106-118. [CrossRef]

19. Bonn, A.; Richter, A.; Vohland, K.; Pettibone, L.; Brandt, M.; Feldmann, R.; Goebel, C.; Grefe, C.; Hecker, S.; Hennen, L.; et al. Grünbuch Citizen Science Strategie 2020 für Deutschland; Helmholtz-Zentrum für Umweltforschung (UFZ); Deutsches Zentrum für Integrative Biodiversitätsforschung (iDiv) Halle-Jena-Leipzig: Leipzig, Germany; Museum für Naturkunde Berlin, Leibniz-Institut für Evolutions-und Biodiversitätsforschung (MfN): Berlin, Germany; Berlin-Brandenburgisches Institut für Biodiversitätsforschung (BBIB): Berlin, Germany, 2016.

20. Seuring, S.A.; Koplin, J.; Behrens, T.; Schneidewind, U. Sustainability assessment in the German detergent industry: From stakeholder involvement to sustainability indicators. Sustain. Dev. 2003, 11, $199-212$. [CrossRef]

21. Cornet, Y.; Gudmundsson, H. Building a metaframework for sustainable transport indicators: Review of selected contributions. Transp. Res. Rec. 2015, 2531, 103-112. [CrossRef]

22. European Commission. A Concept for Sustainable Urban Mobility Plans. Available online: https://ec.europa. eu/transport/sites/transport/files/themes/urban/doc/ump/com\%282013\%29913-annex_en.pdf (accessed on 28 November 2019).

23. Richardson, B.C. Sustainable transport: Analysis frameworks. J. Transp. Geogr. 2005, 13, 29-39. [CrossRef]

24. Schneidewind, U.; Augenstein, K. Analyzing a transition to a sustainability-oriented science system in Germany. Environ. Innov. Soc. Transit. 2012, 3, 16-28. [CrossRef]

25. World Commission on Environment and Development. Our Common Future; Oxford University: Oxford, UK, 1987.

26. Suchanek, M.; Szmelter-Jarosz, A. Environmental aspects of Generation Y's sustainable mobility. Sustainability 2019, 11, 3204. [CrossRef]

27. Luederitz, C.; Schäpke, N.; Wiek, A.; Lang, D.J.; Bergmann, M.; Bos, J.J.; Burch, S.; Davies, A.; Evans, J.; König, A. Learning through evaluation-A tentative evaluative scheme for sustainability transition experiments. J. Clean. Prod. 2017, 169, 61-76. [CrossRef]

28. Liyanage, S.; Dia, H.; Abduljabbar, R.; Bagloee, S.A. Flexible Mobility On-Demand: An Environmental Scan. Sustainability 2019, 11, 1262. [CrossRef]

29. Savelberg, F.; Moorman, S.; Bakker, P. Conditions for Success in Public Transport Innovations. In Proceedings of the 47th European Transport Conference, Barcelona, Spain, 9-11 October 2017; Association For European Transport: Henley-in-Arden, UK, 2017.

30. Beiker, S. Implementation of an automated mobility-on-demand system. In Autonomous Driving; Maurer, M., Gerdes, J.C., Lenz, B., Winner, H., Eds.; Springer: Heidelberg, Germany, 2016; pp. 277-295.

31. Djavadian, S.; Chow, J.Y. An agent-based day-to-day adjustment process for modeling 'Mobility as a Service'with a two-sided flexible transport market. Transp. Res. Part B Methodol. 2017, 104, 36-57. [CrossRef]

32. Greenblatt, J.B.; Shaheen, S. Automated vehicles, on-demand mobility, and environmental impacts. Curr. Sustain./Renew. Energy Rep. 2015, 2, 74-81. [CrossRef]

33. International Transport Forum. Shared Mobility: Innovation for Liveable Cities; Corporate Partnership Board Report; Interantional Transport Forum of the OECD: Paris, France, 2016.

34. Tirachini, A.; Gomez-Lobo, A. Does ride-hailing increase or decrease vehicle kilometers traveled (VKT)? A simulation approach for Santiago de Chile. Int. J. Sustain. Transp. 2019, 13, 1-18. [CrossRef]

35. Jokinen, J.-P.; Sihvola, T.; Mladenovic, M.N. Policy lessons from the flexible transport service pilot Kutsuplus in the Helsinki Capital Region. Transp. Policy 2019, 76, 123-133. [CrossRef]

36. Brandies, A.; König, A.; Viergutz, K.; Fraedrich, E.; Gebhardt, L.; Ulmer, F.; Sippel, T.; Dotzauer, M. Transdisziplinäre Mobilitätsforschung unter Verwendung von Reallaboren: Integration von Stakeholderbedürfnissen und-anforderungen in die Entwicklung von Systemen Bedarfsorientiert 
und Vollautomatisiert Fahrender Quartiersbusse. In Proceedings of the AAET, Braunschweig, Germany, 8-9 February 2017.

37. Becker, E.; Jahn, T. Sozial-ökologische Transformationen. Theoretische und methodische Probleme transdisziplinärer Nachhaltigkeitsforschung. In Nachhaltige Entwicklung und Transdisziplinarität; Brand, K.-W., Ed.; Analytica: Berlin, Germany, 2000; pp. 67-84.

38. Pohl, C. Die Auseinandersetzung zwischen den vielfältigen transdisziplinären Forschungsansätzen ist gefragt! Gaia-Ecol. Perspect. Sci. Soc. 1999, 8, 228-230. [CrossRef]

39. Stilgoe, J.; Owen, R.; Macnaghten, P. Developing a framework for responsible innovation. Res. Policy 2013, 42, 1568-1580. [CrossRef]

40. Oakley, P. Projects with People: The Practice of Participation in Rural Development; International Labour Organization: Geneva, Switzerland, 1991.

41. Cleaver, F. Paradoxes of participation: Questioning participatory approaches to development. J. Int. Dev. J. Dev. Stud. Assoc. 1999, 11, 597-612. [CrossRef]

42. Cooke, B.; Kothari, U. Participation: The New Tyranny? Zed books: London, UK, 2001.

43. Klein, J.T. A taxonomy of interdisciplinarity. In The Oxford Handbook of Interdisciplinarity; Frodeman, R., Thompson Klein, J., Mitcham, C., Eds.; Oxford University Press: Oxford, UK, 2010; pp. 15-30.

44. Pohl, C.; Hirsch Hadorn, G. Principles for Designing Transdisciplinary Research-Proposed by the Swiss Academies of Arts and Sciences; Oekom Verlag: Munich, Germany, 2007.

45. Defila, R.; Di Giulio, A. Partizipative Wissenserzeugung und Wissenschaftlichkeit-ein methodologischer Beitrag. In Transdisziplinär und Transformativ Forschen. Eine Methodensammlung; Defila, R., Di Giulio, A., Eds.; Springer VS: Wiesbaden, Germany, 2018; pp. 39-67.

46. Martin, D.H. Two-eyed seeing: A framework for understanding indigenous and non-indigenous approaches to indigenous health research. Can. J. Nurs. Res. 2012, 44, 20-42.

47. Repko, A.F. Integrating theory-based insights on the causes of suicide terrorism. In Case Studies in Interdisciplinary Research; Repko, A.F., Newell, W.H., Szostak, R., Eds.; Sage: Thousand Oaks, CA, USA, 2012; pp. 125-157.

48. Bergmann, M.; Jahn, T.; Knobloch, T.; Krohn, W.; Pohl, C.; Schramm, E. Methoden Transdisziplinärer Forschung. Ein Überblick mit Anwendungsbeispielen; Campus Verlag: Frankfurt am Main, Germany, 2010.

49. Eckardt, F. Stadtforschung. Gegenstand und Methoden; Eckardt, F., Ed.; Springer VS: Wiesbaden, Germany, 2014.

50. Burton, R.; Rønningen, K.; Wedderburn, L. Conducting Integrated Research: A critical Literature Review of Interdisciplinary and Transdisciplinary Research. Report/Centre for Rural Research 2008. Research 2008. Available online: https://ruralis.no/en/publications/r-1208-conducting-integrated-research-acritical-literature-review-of-interdisciplinary-and-transdisciplinary-research/ (accessed on 29 November 2019).

51. Defila, R.; Di Giulio, A. Interdisziplinarität und Disziplinarität. In Zwischen den Fächern—über den Dingen? Olbertz, J.-H., Ed.; Springer: Wiesbaden, Germany, 1998; pp. 111-137.

52. Klein, J.T. Interdisciplinarity and transdisciplinarity: Keyword meanings for collaboration science and translational medicine. J. Transl. Med. Epidemiol. 2014, 2, 1024-1030.

53. Mobjörk, M. Consulting versus participatory transdisciplinarity: A refined classification of transdisciplinary research. Futures 2010, 42, 866-873. [CrossRef]

54. Beecroft, R. Embedding Higher Education into a Real-World Lab: A Process-Oriented Analysis of Six Transdisciplinary Project Courses. Sustainability 2018, 10, 3798. [CrossRef]

55. De Flander, K.; Hahne, U.; Kegler, H.; Lang, D.; Lucas, R.; Schneidewind, U.; Simon, K.-H.; Singer-Brodowski, M.; Wanner, M.; Wiek, A. Resilience and real-life laboratories as key concepts for urban transition research. Gaia-Ecol. Perspect. Sci. Soc. 2014, 23, 284-286. [CrossRef]

56. Schneidewind, U. Urbane Reallabore-ein Blick in die aktuelle Forschungswerkstatt. PND Online 2014, 2014, 1-7.

57. Schäpke, N.; Stelzer, F.; Bergmann, M.; Singer-Brodowski, M.; Wanner, M.; Caniglia, G.; Lang, D.J. Reallabore im Kontext transformativer Forschung: Ansatzpunkte zur Konzeption und Einbettung in den internationalen Forschungsstand. In IETSR Discussion Papers in Transdisciplinary Sustainability Research; Leuphana University Lüneburg: Lüneburg, Germany, 2017.

58. WBGU. Welt im Wandel. In Gesellschaftsvertrag für eine Große Transformation. Hauptgutachten; Wissenschaftlicher Beirat der Bundesregierung Globale Umweltveränderungen: Berlin, Germany, 2011. 
59. Jahn, T.; Keil, F. Reallabore im Kontext transdisziplinärer Forschung. Gaia-Ecol. Perspect. Sci. Soc. 2016, 4, 247-252. [CrossRef]

60. Bracco, S.; Delfino, F.; Laiolo, P.; Morini, A. Planning \& Open-Air Demonstrating Smart City Sustainable Districts. Sustainability 2018, 10, 4636. [CrossRef]

61. Nevens, F.; Frantzeskaki, N.; Gorissen, L.; Loorbach, D. Urban Transition Labs: Co-creating transformative action for sustainable cities. J. Clean. Prod. 2013, 50, 111-122. [CrossRef]

62. Schäpke, N.; Bergmann, M.; Stelzer, F.; Lang, D.J. Labs in the Real World: Advancing Transdisciplinary Research and Sustainability Transformation: Mapping the Field and Emerging Lines of Inquiry. Gaia-Ecol. Perspect. Sci. Soc. 2018, 27, 8-11. [CrossRef]

63. Scholz, R. The normative dimension in transdisciplinarity, transition management, and transformation sciences: New roles of science and universities in sustainable transitioning. Sustainability 2017, 9, 991. [CrossRef]

64. Voorberg, W.H.; Bekkers, V.J.; Tummers, L.G. A systematic review of co-creation and co-production: Embarking on the social innovation journey. Public Manag. Rev. 2015, 17, 1333-1357. [CrossRef]

65. Bradwell, P.; Marr, S. Making the Most of Collaboration: An International Survey of Public Service Co-Design; Demos Report 23; PwC's Public Sector Research Centre: London, UK, 2008.

66. Senate Department for Environment, Construction and Transport. Sustainable Urban Mobility Plan Bremen 2025; Senate Department for Environment, Construction and Transport: Bremen, Germany, 2014. Available online: File://C:/Users/koen_al/AppData/Local/Microsoft/Windows/INetCache/IE/11N939WU/ SUMP_Bremen2025_web.pdf (accessed on 2 December 2019).

67. Finke, P. Citizen Science. Das Unterschätzte Wissen der Laien; Oekom Verlag: Munich, Germany, 2014.

68. Franz, Y.; Tausz, K.; Thiel, S.-K. Contextuality and co-creation matter: A qualitative case study comparison of living lab concepts in urban research. Technol. Innov. Manag. Rev. 2015, 5, 48-55. [CrossRef]

69. Juujärvi, S.; Pesso, K. Actor roles in an urban living lab: What can we learn from Suurpelto, Finland? Technol. Innov. Manag. Rev. 2013, 3, 22-27. [CrossRef]

70. Menny, M.L. Users as Co-Creators?-An Analysis of User Involvement in Urban Living Labs. IIIEE. Master's Thesis, The International Institute for Industrial Environmental Economics, Lund University, Lund, Sweden, 2016.

71. Buhr, K.; Federley, M.; Karlsson, A. Urban living labs for sustainability in suburbs in need of modernization and social uplift. Technol. Innov. Manag. Rev. 2016, 6, 27-34. [CrossRef]

72. Schuurman, D.; De Marez, L. Structuring user involvement in panel-based Living Labs. Technol. Innov. Manag. Rev. 2012, 2, 31-38. [CrossRef]

73. Menny, M.; Palgan, Y.V.; McCormick, K. Urban living labs and the role of users in co-creation. Gaia-Ecol. Perspect. Sci. Soc. 2018, 27, 68-77. [CrossRef]

74. Schuurman, D.; De Marez, L.; Ballon, P. Living Labs: A systematic literature review. In Proceedings of the Open Living Lab Days, Istanbul, Turkey, 24-28 August 2015.

75. König, A.; Karnahl, K.; Gebhardt, L.; Klötzke, M. Reallabor Schorndorf-Bedarfsgesteuerte Mobilität gemeinsam gestalten. In Proceedings of the 12 Deutscher Nahverkehrstag, Koblenz, Germany, 24-26 April 2018.

76. Gebhardt, L.; König, A. Die TraSy-Methode-ein Vorgehen für die transdisziplinäre Entwicklung soziotechnischer Systeme. In Transdisziplinär und Transformativ Forschen; Di Giulio, A., Defila, R., Eds.; Springer VS: Wiesbaden, Germany, 2019; Volume 2, pp. 191-236.

77. Joss, S.; Bellucci, S. Participatory Technology Assessment in Europe: Introducing the EUROPTA Research Project. In Participatory Technology Assessment: European Perspectives; Joss, S., Bellucci, S., Eds.; Center for the Study of Democracy: London, UK, 2002; pp. 3-14.

78. Hennen, L. Why do we still need participatory technology assessment? Poiesis Prax. 2012, 9, 27-41. [CrossRef] [PubMed]

79. Kucharski, A.; Merkel, S. Partizipative Technikentwicklung von Gerontotechnologie: Ansätze für mehr Akzeptanz in der Zielgruppe. Forsch. Aktuell 2018, 6, 1-15.

80. Bergold, J.; Thomas, S. Partizipative Forschungsmethoden: Ein methodischer Ansatz in Bewegung. Forum Qual. Soz. 2012, 13, 30. [CrossRef]

81. Müller, J.; Renyi, M.; Kunze, C. Partizipative Technikentwicklung für ein selbstbestimmtes Leben im Alter ? ein Exkurs. Participartory technology development for an independent life for senior citizens. In Proceedings 
of the Transdisziplinäre Konferenz zum Thema, Technische Unterstützungssysteme, die die Menschen wirklich wollen, Hamburg, Germany, 15-16 December 2014.

82. Veeckman, C.; Schuurman, D.; Leminen, S.; Westerlund, M. Linking living lab characteristics and their outcomes: Towards a conceptual framework. Technol. Innov. Manag. Rev. 2013, 3, 7-15. [CrossRef]

83. Plattner, H.; Meinel, C.; Leifer, L. Design Thinking: Understand-Improve-Apply; Springer Science \& Business Media: Heidelberg, Germany, 2011. [CrossRef]

84. Kramer, S. Zeit für Mobilität. Räumliche Disparitäten der Individuellen Zeitverwendung für Mobilität in Deutschland; Franz Steiner Verlag: Stuttgart, Germany, 2005; Volume 138.

85. Scheiner, J. Aktionsraumforschung auf phänomenologischer und handlungstheoretischer Grundlage. Geogr. Z. 1998, 86, 50-66.

86. Hannam, K.; Sheller, M.; Urry, J. Editorial: Mobilities, Immobilities and Moorings. Mobilities 2006, 1, 1-22. [CrossRef]

87. Miebach, B. Soziologische Handlungstheorie: Eine Einführung; VS Verlag für Sozialwissenschaften: Wiesbaden, Germany, 2006.

88. Watson, M. How theories of practice can inform transition to a decarbonised transport system. J. Transp. Geogr. 2012, 24, 488-496. [CrossRef]

89. Fraedrich, E. How collective frames of orientation toward automobile practices provide hints for a future with autonomous vehicles. Appl. Mobil. 2018, 1-20. [CrossRef]

90. Grosvenor, T. Qualitative Research in the Transport Sector. Transportation Research E-CIRCULAR. Transport Surveys. Raising the Standard. In Proceedings of the an International Conference on Transport Survey Quality and Innovation, Grainau, Germany, 24-30 May 1997. 2000 II-K.

91. Blühdorn, I. Simulative Demokratie. Neue Politik nach der Postdemokratischen Wende; Edition Suhrkamp: Berlin, Germany, 2013.

92. Arlanch, S. BürgerInnenrat: Leitbilder in der Perspektive von Gemeinwesenarbeit und Governance; Verein zur Förderung der sozialpolitischen Arbeit: Neu-Ulm, Germany, 2011.

93. Klöti, T.; Drilling, M. Warum Eigentlich Partizipation? Sozialwissenschaftliche Analyse Aktueller Partizipationsverständnisse in der Planung, Gestaltung und Nutzung öffentlicher Räume; Fachhochschule Nordwestschweiz, Hochschule für Soziale Arbeit, Institut Sozialplanung und Stadtentwicklung: Basel, Switzerland, 2014.

94. Glaser, B.G.; Strauss, A.L. Discovery of Grounded Theory: Strategies for Qualitative Research; Routledge: New York, NY, USA, 2017.

95. Charmaz, K. Constructing Grounded Theory. A Practical Guide through Qualitative Analysis, 2nd ed.; Sage Publications: London, UK, 2014.

96. Cole, P.S.; Martin, M.G. How to Write a Statement of Work; Berrett-Koehler Publishers: San Francisco, CA, USA, 2012.

97. Sokowski, D. Mastering Project Management Integration and Scope: A Framework for Strategizing and Defining Project Objectives and Deliverables; Pearson Education: Upper Settle River, NJ, USA, 2015.

98. Brost, M.; Klötzke, M.; Kopp, G.; Deißer, O.; Fraedrich, E.-M.; Karnahl, K.; Sippel, T.; Müller, A.; Beyer, S. Development, Implementation (Pilot) and Evaluation of a Demand-Responsive Transport System. World Electr. Veh. J. 2018, 9, 4. [CrossRef]

99. Statistisches Landesamt Baden-Württemberg. Bevölkerung nach Altersgruppen und Geschlecht, Auswertung für die Stadt Schorndorf. Website City of Schorndorf 2016. Available online: https://www.schorndorf.de/de/ stadt-buerger/die-daimlerstadt/stadtportrait/zahlen-fakten (accessed on 2 December 2019).

100. Dubielzig, F.; Schaltegger, S. Methoden Transdisziplinärer Forschung und Lehre. Ein Zusammenfassender Überblick; Centre for Sustainability Management, University of Lueneburg: Lueneburg, Germany, 2004.

101. Mitchell, V.; Ross, T.; May, A.; Sims, R.; Parker, C. Empirical investigation of the impact of using co-design methods when generating proposals for sustainable travel solutions. CoDesign 2015, 12, 205-220. [CrossRef]

102. Zmud, J.P.; Sener, I.N. Towards an understanding of the travel behavior impact of autonomous vehicle. Transp. Res. Procedia 2017, 25, 2500-2519. [CrossRef]

103. Parodi, O.; Waitz, C.; Bachinger, M.; Kuhn, R.; Meyer-Soylu, S.; Alcántara, S.; Rhodius, R. Insights into and recommendations from three real-world laboratories: An experience-based comparison. Gaia-Ecol. Perspect. Sci. Soc. 2018, 27, 52-59. [CrossRef] 
104. Michelsen, D.; Walter, F. Unpolitische Demokratie. Zur Krise der Repräsentation; Suhrkamp: Berlin, Germany, 2013.

105. Kolleck, A. Online mitbestimmen? Perspektiven und Herausforderungen internetbasierter Partizipationsverfahren. Enewslett. Netzw. Bürgerbeteil. 2016, 4, 1-8.

106. Gong, G.; Hsiao, M.; Hsieh, M.-D.; Liu, L.; Chiu, T.; Lin, L.-C.; Chen, K.-T.; Chen, B.; Lin, H.-H.; Fang, E. Application of the living lab concept: Empirical validation in Taiwan's Minsheng community. Int. J. Autom. Smart Technol. 2012, 2, 209-229. [CrossRef]

107. Cellina, F.; Bucher, D.; Rudel, R.; Raubal, M.; Rizzoli, A.E. Promoting sustainable mobility styles using eco-feedback and gamification elements: Introducing the GoEco! Living lab experiment. In Proceedings of the 4th European Conference on Behaviour and Energy Efficiency, Coimbra, Portugal, 8-9 September 2016.

108. Evans, J.; Karvonen, A. Living laboratories for sustainability: Exploring the politics and epistemology of urban transition. In Cities and Low Carbon Transitions; Bulkeley, H., Castan-Broto, V., Hodson, M., Marvin, S., Eds.; Routledge: London, UK, 2011; pp. 126-141.

109. Martin, G.P. Ordinary people only': Knowledge, representativeness, and the publics of public participation in healthcare. Sociol. Health Illn. 2008, 30, 35-54. [CrossRef]

110. Taylor, M. Community participation in the real world: Opportunities and pitfalls in new governance spaces. Urban Stud. 2007, 44, 297-317. [CrossRef]

(C) 2019 by the authors. Licensee MDPI, Basel, Switzerland. This article is an open access article distributed under the terms and conditions of the Creative Commons Attribution (CC BY) license (http://creativecommons.org/licenses/by/4.0/). 